\title{
The eye looks back: Seeing and being seen from William Bartram to H.P. Lovecraft
}

\author{
MAREK WILCZYŃSKI
}

Received 31.01.2018, accepted 30.11.2018.

\begin{abstract}
The paper focuses on the sense of sight and seeing in the selected texts of American literature from the late $18^{\text {th }}$ century to the $1930 \mathrm{~s}$, i.e. from William Bartram to H. P. Lovecraft. Adopting a perspective of changing "scopic regimes" - conventions of visual perception presented in a number of literary and non-literary works, the author analyzed a passage from Bartram's Travels to reveal a combination of the discourse of science with that of the British aesthetics of gardening. In Margaret Fuller's Summer on the Lakes (1843) the main factor is the work of imagination dissatisfied with the actual view of Niagara Falls, while in Ralph Waldo Emerson's Nature substantial subjectivity is reduced to pure seeing. In Henry David Thoreau's essay "Ktaadn" the subject confronts nature that is no longer transparent and turns out meaningless. In American literature of horror from Charles Brockden Brown through Edgar Allan Poe and H. P. Lovecraft, the narrator's eye encounters the inhuman gaze of a predator, a dehumanized victim of murder, or a sinister creature from the outer space. To conclude, the human gaze was gradually losing its ability to frame or penetrate nature, bound to confront the annihilating evil eye from which there was usually no escape.
\end{abstract}

\section{Keywords}

eye, seeing, gaze, scopic regime, nature, subjectivity 


\title{
Spojrzenie w odpowiedzi: podmiot i przedmiot widzenia od Bartrama do Lovecrafta
}

\begin{abstract}
Abstrakt
Tematem artykułu jest zmysł wzroku i widzenie w wybranych tekstach literatury amerykańskiej od drugiej połowy wieku XVIII do lat trzydziestych wieku XX, czyli od W. Bartrama do H. P. Lovecrafta. Przyjmujac perspektywę zmiennych „dyskursów skopicznych”, czyli konwencji postrzegania świata utrwalonych w różnego rodzaju utworach o charakterze literackim bądź paraliterackim, autor poddał analizie fragment Travels Bartrama, by odsłonić w nim połaczenie dyskursu naukowego $z$ dyskursem zapożyczonym $z$ angielskiej estetyki ogrodów. W Summer on the Lakes M. Fuller $z$ roku 1843 na plan pierwszy wychodzi praca wyobraźni rozczarowanej rzeczywistym widokiem wodospadu Niagara, podczas gdy u R. W. Emersona (Natura) czytelnik ma do czynienia $z$ samozaprzeczeniem substancjalnego podmiotu zredukowanego do czystego widzenia. $Z$ kolei u H. D. Thoreau (Ktaadn) podmiot zderza się $z$ natura nieprzenikniona, która odmawia ujawnienia jakiegokolwiek sensu. W prozie gotyckiej od Ch. Brockdena Browna, poprzez E. A. Poego aż do Lovecrafta oko podmiotu (narratora) napotyka niekiedy na spojrzenie nieludzkie: drapieżnego zwierzęcia, odczłowieczonej ofiary mordu, złowrogiej istoty pozaziemskiej. W literaturze amerykańskiej spojrzenie stopniowo traci swoja siłę ujmowania i przenikania natury, $z$ drugiej zaś strony napotyka w świecie oko złe, spojrzenie unicestwiające, przed którym najczęściej nie ma ucieczki.
\end{abstract}

\section{Słowa kluczowe}

oko, spojrzenie, dyskurs postrzegania, natura, podmiot

The present essay is not a rigorously argued study of some specific, chronologically limited aspect of American literature, but rather an overview of the vicissitudes of the subject from the mid-eighteenth to the mid-twentieth century, focusing on the "ways of seeing" nature and other human or non-human beings that imply power relations, including, in the case of 
gothic fiction, a possibility of the subject's annihilation. The sense of sight will not be approached in any precise physiological or epistemological terms, but rather as a metaphor that fitted different contexts and served various American writers, from William Bartram in the $18^{\text {th }}$ century to H. P. Lovecraft in the $20^{\text {th }}$, as a more or less effective instrument of the subject's self-fashioning.

Probably the first white American who saw New England nature not just as a series of handwritten messages from the Almighty, the Foucauldian "writing of things" (Foucault 1973: 35), but also, at least to some extent, as a set of beautiful objects in their own right was Jonathan Edwards. Expelled in 1750 from his Northampton parish for verbally harassing the meeting house audience to live in the woods fifty miles west and bring spiritual care to Indians, he started penning his last, unfinished work, edited two hundred years later by Perry Miller under the title Images or Shadows of Divine Things. This rather traditional allegorical Puritan reading of the "wilderness" ends with a somewhat surprising brief expression of praise of nature almost "as is", called simply "The Beauty of the World":

It is very probable that [the] wonderful suitableness of green for the grass and plants, the blues of the skie, the white of the clouds, the colours of flowers, consists in a complicated proportion that these colours make one with another, either in their magnitude of the rays, the number of vibrations that are caused in the atmosphere, or some other way. So there is a great suitableness between the objects of different senses, as between sounds, colours, and smells; as between colours of the woods and flowers and the smells and the singing of birds, which is its probable consist in a certain proportion of the vibrations that are made in the different organs. So there are innumerable other agreeablenesses of motions, figures, etc. (Edwards 1977: 135)

Edwards remained a staunch Calvinist till the end of his days in 1758, yet as a reader of Locke he combined a theologian's 
diction with a new, empiricist discourse of the senses that eventually brought him to the sheer joy of seeing, hearing, and smelling. Mason Lowance writes: "More closely related to the Puritan habit of discovering 'remarkable Providences' in the natural universe than to the Puritan doctrine of tropological exegesis, Edwards's typology here is more like the epistemology of his empiricist contemporaries than that of his Puritan predecessors" (Lowance 1980: 261). In other words, despite the persistence of the Puritan intellectual background, in the mid$18^{\text {th }}$ century New England had a chance to hear the voice of the new science. Paradoxically, that chance was missed since Edwards's notes remained in manuscript till 1948.

Three years before Edwards's premature death, William Bartram, then sixteen years old, accompanied his father, a noted botanist, on a research expedition to the colonies of Connecticut and New York. Eleven years later, much better educated and prepared, he joined the father on another trip, that time to Florida. Eventually, in 1773, he started a series of professional travels on his own, which ended in 1777 after providing him with ample material for a long report, published in 1791. As a result, William Bartram became the most outstanding and famous natural scientist of the Early Republic.

His expertise was well-founded and authentic. He knew his Linnaeus by heart, naming all the plants on his way in Latin according to their scientific classification and giving names to the still nameless ones whenever necessary. His descriptions were accurate, yet sometimes they seemed to reach beyond the pale of science. For instance, in 1774, ascending St. John's River in Florida, he wrote:

In being a fine, cool morning, and fair wind, I sat sail early, and so, this day, vast quantities of the Pistia stratiotes, a very singular aquatic plant. It associates in large communities, or floating islands, some of them a quarter of a mile in extent, which are impelled to and fro, as the wind and current may direct. ... These plants are nourished and kept in their proper horizontal situation, by means of long fibrous roots, which descend from the nether 
center, downwards, towards the muddy bottom. Each plant, when full grown, bears a general resemblance to a well grown plant of garden lettuce, though the leaves are more nervous, of a firmer contexture, and of a full green colour, inclining to yellow. (Bartram 1996: 92)

Here reigns the idiom of the scientist, as precise as it could be at that time, combined with an effort to make the peculiar Pistia stratiotes more familiar to the lay reader thanks to a comparison with garden lettuce, but the concluding part of the passage shows a significant change of the dominant discourse:

These floating islands present a very entertaining prospect; for although we behold an assemblage of the primary productions of nature only, yet the imagination seems to remain in suspense and doubt; as in order to enliven the delusion, and form a most picturesque appearance, we see not only flowery plants, clumps of shrubs, old weather-beaten trees, hoary and barbed, with the long moss waving from their snags, but we also see them completely inhabited, and alive, with serpents, frogs, otters, crows, herons, curlews, jackdaws, \&c. There seems, in short, nothing wanted but the appearance of a wigwam and a canoe to complete the scene. (Bartram 1996: 93)

The most important keyword in this passage is "imagination", a term not infrequently used by the art theorists, critics, poets, and scientists of the Enlightenment. Another keyword is the adjective "picturesque", definitely not taken from the vocabulary of Linnaeus but from that of the English eighteenthcentury theorists of landscape gardening. When combined, imagination and the picturesque turned the empirically tested view of St. John's River into a frame complete with the animals and birds that were actually not there, and the metonymic traces of Indians - a wigwam and a canoe - though the Indians themselves were missing. Undoubtedly the whole extended paragraph has two patrons: the Swedish natural scientist and Edmund Burke. As Pamela Regis argues, "The Burkean mode of description provides Bartram with a means of objectively 
representing his reactions to the locales through which he travels. Taken together with the natural historical mode, the two forms of description represent to the reader the natural scenes observed in America and the effects of those scenes on the observer" (Regis 1992: 70). The scientific intellect imposes on reality its specialist verbal network of terms, but at the same time the eye turns the view into a picture. As a result, the subject takes what he can see under double control.

About half a century later, on June 10, 1843, Margaret Fuller arrived during her trip to the Great Lakes at Niagara Falls. Having read a great deal about that famous wonder of American nature, which was a tourist trap even then (Sears 1989: 12-30), she was, however, doubly disappointed: first, with the waterfall, which she had imagined much bigger and more impressive, and second, with herself since she proved unable to appreciate the view as she should have according to the books. Embarrassed, she kept returning to contemplate the falling water for three days in a row until finally she wrote with some relief, mixed with awe:

Before coming away, I think I really saw the full wonder of the scene. After awhile it so drew me into itself as to inspire an undefined dread, such as I never knew before, such as may be felt when death is about to usher us into a new existence. The perpetual trampling of the water seized my senses. I felt that no other sound, however near, could be heard, and would start and look behind me for a foe. I realized the identity of that mood of nature in which these waters were poured down with such absorbing force, with that in which the Indian was shaped on the same soil. For continually upon my mind came, usought and unwelcome, images, such as never haunted it before, of naked savages stealing behind me with uplifted tomahawks; again and again this illusion recurred, and even after I had thought it over, and tried to shake it off, I could not help starting and looking behind me. (Steele 1995: 72)

In this case, everything begins on the level of the senses again, apparently as in the quoted passage from Bartram's Travels, 
but the stage of the sensory perception lasts only for an instant, to be followed by that of an emotional response. Fuller has the experience of the sublime - another Burkean concept a mélange of joy and fear that almost immediately gives way to an imagined view of "naked savages", aggressive Indians with tomahawks who seem to supplement Bartram's incomplete frame although this supplement is by no means serene. The author of Summer on the Lakes clearly needed those Indians to become scared enough and perhaps also to articulate her desire at the boundary of the Imaginary and the Symbolic: on the one hand, in 1843, the violent confrontation between the "savages" and the white settlers was already a well-established element of the US symbolic order, on the other, the "savage" warriors did not have habit of going on the warpath stark naked. Fuller's control of the natural scene with the eye also required imagination, but her eye belonged to a subject that was much "weaker" and more disturbed than the scientist-painter.

When considering the vicissitudes of the eye in nineteenthcentury American culture, it is virtually impossible to ignore Emerson's "transparent eyeball" from Chapter I of Nature. Emerson did not really like uncivilized places. He did not like to travel to see distant rivers or waterfalls, and usually felt satisfied with walks on Boston or Concord common and visits paid to his friend Thoreau at Walden Pond located about a mile from his house. As all students of American literature know, the famous core of Nature's Chapter I is the following: "Standing on the bare ground, - my head bathed by the blithe air, and uplifted into infinite space, - all mean egotism vanishes. I am nothing. I see all. The currents of the Universal Being circulate through me; I am part or particle of God" (Spiller 1971: 10). These four sentences, familiar as they may have become, are indeed strange. First, Emerson's body grew so much that it seemed to have penetrated at least into the stratosphere. (A fellow-transcendentalist, the artist Christopher Pearse Cranch, was so impressed by this that it inspired him to draw a caricature of the philosopher.) Second, in the next sentence 
the subject vanishes, though it keeps speaking. (This moment oddly brings to mind the climactic confession of Poe's M. Valdemar, a Pole allegedly hypnotized in articulo mortis in New York's Haarlem: "Yes; - no; - I have been sleeping - and now now - I am dead" (Mabbott 1978: 1240). Emerson's "I" also both is and is not: the English language, which allowed Poe to write the perfectly good sentence "I am dead", gave a similar possibility to his confirmed enemy, who plays with the tension between the affirmative "I am" and the negative "nothing".) Third, "I see all," even though it suggests all-embracing visual omnipotence, cannot match what is really "all". How is it possible to visualize this all and what does it actually offer to the reader? Besides, "all" is not particularly American, a general term as full as it is empty. In consequence, there is little left for the Emersonian subject to do but transform into a particle of God to whom no sense impressions can legitimately refer. The eye has acquired much power, but its power can hardly be used to perceive the world.

Carolyn Porter makes a point when she claims: "Emerson wipes away all the clutter of culture which he finds obstructing his vision in order to forge an 'original' relation between man and nature, a relation free of alienation [...], but constructs a theory in which alienation resurfaces as a split between the I who sees nature and the I who inhabits it" (Porter 1981: 106107). In fact, however, under the circumstances one cannot be sure what that "I" sees and whether it still inhabits as a creature of flesh and blood the city of Boston, Massachusetts. The "transparent eyeball" passage turns out to be an ambiguous record of self-denial.

Emerson and Thoreau were both transcendentalists and personal friends, but Thoreau's visual experience of nature brought him to surprisingly different conclusions. In 1846, going down Mount Katahdin in the company of lumberjacks, he traversed an area devastated by a natural forest fire, which left him almost speechless. Realizing that the burnt out stretch did not belong to anyone and indeed had nothing to do with 
human beings, the writer lacked words that would even vaguely correspond to the space before his eyes:

It is difficult to conceive of a region uninhabited by man. We habitually presume his presence and influence everywhere. [...] Nature was here something savage and awful, though beautiful. I looked with awe at the ground I trod on, to see what the Powers had made there, the form and fashion and material of their work. This was that Earth of which we have heard, made out of Chaos and Old Night. Here was no man's garden, but the unhandselled globe. It was not lawn, nor pasture, nor mead, not woodland, nor lea, nor arable, nor waste-land. It was the fresh and natural surface of the planet Earth, as it was made forever and ever, - to be the dwelling of man, we say, - so Nature made it, and man may use it if he can. (Thoreau 1972: 70)

This passage from "Ktaadn", an essay included in Maine Woods, also famous enough, reads like the opposite of the "transparent eyeball" one. While Emerson was comfortable and delighted, Thoreau felt uneasy and helpless. His rhetorical skill almost failed him, but fortunately his Harvard education came to the rescue. First, summoning the plural "Powers", he made a probable reference to Goethe, popular among the members of the Transcendental Club, then quoted from Book V of Milton's Paradise Lost ("Chaos and Old Night"), and finally paraphrased pseudo-Dionysius the Areopagite; the unique one-page Chapter $\mathrm{V}$ of the tract on mystical theology which is the foundation of the via negativa, listing what God is not and thereby possibly coming closest to Him. At any rate, He remained outside nature. There were no "currents of Universal Being" around him and the self was painfully alienated from the matter that surrounded it. Emerson's "I" dissolved, leaving only an eye. Thoreau, in contrast, confronted something hopelessly opaque and inaccessible.

Still, self-effacement or self-exclusion were not the only dangers faced by the American eye and the subject to whom it belongs. The first case in this respect can probably be found in 
Edgar Huntly, Charles Brockden Brown's novel of 1799, one of the first examples of the vernacular New World gothic. The protagonist, who is a somnambulist and, when asleep, takes long walks far away from home, once wakes up in an unknown dark place where his senses, in particular the sense of sight, cannot provide him with any reliable knowledge of his whereabouts. Moving slowly ahead in what is a long underground cavern, suddenly he sees before himself two small green lights: "They resembled a fixed and obscure flame. They were motionless. Though lustrous themselves they created no illumination around them. This circumstance, added to others, which reminded me of similar objects, noted on former occasions, immediately explained the nature of what I beheld. These were the eyes of a panther" (Brockden Brown 1984: 166).

If Edgar can see the panther's eyes, certainly the animal can see him in the dark much better, as it prepares to leap at him and kill him. Brockden Brown's character not only sees something mortally dangerous, but also is seen by the predator, and only animal-like reflex and an Indian tomahawk, found by accident and used just in time, saves his life. Thus, being seen was defined as a serious predicament, a prelude to the ultimate, a trap from which there is almost no escape. Even the victory was costly: after the encounter with the panther and then with five Indians whom he also has to kill one after another, Edgar transforms into an alien monster, unrecognizable as a gentle, white boy by the party of local vigilanti who are trying to find the hostile redskins on their own. What is more, the young man can no longer recognize himself. Before the dramatic adventure, he was neither an expert hunter, nor a good warrior. Killing the wild animal proves to be the trigger that releases his dark, destructive side, which can only with difficulty be brought back under control.

No control is possible in Poe's "The Tell-Tale Heart" (1843), a tale of horror which follows Brockden Brown's pattern, where seeing and being seen are absolutely crucial. The nameless narrator feels compelled to kill the old man whom he loves and 
whose gold he does not want, but he cannot stand the look of the old man's eye which is referred to as "that of a vulture a pale blue eye with a film over it" (Mabbott 1978: 792). Since the vulture, which feeds on carrion, is considered a bird of death, it is obvious almost from the very beginning that the narrator identifies his victim with death itself, so in killing him, he wants, as it were, to kill death, a task it is unlikely he can successfully perform. When on the night of the murder the assassin slowly opens the old man's bedroom door, the latter is fast asleep, so his fearful gaze does not pose any threat. After some time, however, he hears a noise and can no longer sleep, afraid as he is that something horrible may happen to him. Since the man is awake, his eyes are open and when a single ray from the narrator's lamp falls upon the "vulture's eye" - "all a dull blue, with a hideous veil over it that chilled the very marrow in [his] bones" (Mabbott 1978: 795) - there is no time left for deliberation. With a "loud yell" and a single leap (like a panther indeed), the murderer does what he has been planning carefully for many days, to get only some temporary relief.

Still waiting on the threshold in pitch dark, at a certain moment Poe's narrator makes a significant observation, prompted by his acute sense of hearing:

Presently I heard a slight groan, and I knew it was the groan of mortal terror. It was not a groan of pain or of grief - oh, no! - it was the low stifled sound that arises from the bottom of the soul when overcharged with awe. I knew the sound well. Many a night, just at midnight, when all the world slept, it has welled up from my own bosom, deepening, with its dreadful echo, the terrors that distracted me. (Mabbott 1978: II 794)

Thus, the two protagonists are bound together by two senses: hearing and seeing, with the former as a more important and consequential link since both seeing and being seen bring fear and eventually lead to death. Analyzing "The Tall-Tale Heart" in psychoanalytic terms, Robert Con Davis recapitulates 
Freud's considerations on the scopic (visual) drive and its dialectic. First,

"looking" is a gesture toward control, visual "possession" or "mastery" of an object. It is discrete and without any reciprocal response, a frozen act. After this initial look takes place, there is a reversal, a seemingly impossible shift from a subject's viewpoint to an object's. This shift entails a virtual "giving up of the object as a thing to be seen and mastered" and a repositioning of "seeing" from a different position. The looker, in effect, becomes an object. In one sense, what happens here is that the looker first looks and, as a part of looking, as a kind of culmination of possessing the object, becomes that object; as a result, the subject surrenders visual mastery, as it then enters the field of vision as an object in a different position. (Davis 1983: 985)

Second, then, the scene, as far as the position of each of the participants is concerned, turns upside down:

The object position here - as if occult - virtually looks back at the (former) subject. With this elaboration of subject and object relations, wherein the direction of sight has been reversed, and wherein the complete expression of seeing has become necessarily twofold - seeing and being seen - the whole process of "seeing" has gone, additionally, through a middle range, neither active nor passive, in which the looker - in the stage of becoming an object is a partial object, one looking at itself, part subject and part object. (Davis 1983: 986)

This account of the process cannot, of course, refer to the encounter of Edgar Huntly with the panther since we are unable to reconstruct the animal perception without making an error of anthropomorphism, but the "vulture" in Poe's tale is, again, just a metaphor that conceals a human subject. Finally, as Davis writes, echoing Freud, "in the last scene the looker is made passive, fully an object for another watcher" (Davis 1983: 986). In "The Tell-Tale Heart", it does not matter that the alleged watcher is already dead. His eyes are closed and his 
quartered body rests under the floorboards, yet his heart still keeps beating in his killer's mind, which means that the sense of hearing proves indispensable as a prosthesis of seeing, the evidence of being "seen" also after the see-er's death. The conclusion is that once the dialectic of seeing and being seen has been put in motion, it cannot be stopped, and in Poe's fiction, with the fear of death as a ubiquitous underpinning, there is no escape to a safe haven where one can remain invisible alive - forever.

Poe's best known continuator and self-proclaimed disciple was Howard Philips Lovecraft, author of a short story entitled "The Haunter of the Dark" (1935). The story, in opposition to Poe's usually indefinite settings, is set in Lovecraft's native Providence, Rhode Island. The protagonist, a student of painting named Robert Blake, who lives on College Hill just opposite Federal Hill (both locations authentic), starts exploring an abandoned church on the Hill, and at last dies in mysterious circumstances. Exploring the boarded-up interior, he first finds in the rear vestry room beside the apse an impressive collection of books about different occult cults and mysteries, then climbs the church tower and there, at the top, discovers a strange "egg-shaped or irregularly spherical object some four inches through" (Lovecraft 1963: 101-102). As it turns out, the object is a "Shining Trapezohedron", a stone that once allowed the members of an ill-famed sect active in the 19th century to communicate with some unknown dimension. Driven by curiosity, Blake looks into the stone where an ominous sight meets his eye:

He saw processions of robed, hooded figures whose outlines were not human, and looked on endless leagues of desert lined with carved, sky-reaching monoliths. He saw towers and walls in nighted depths under the sea, and vortices of space where wisps of black mist floated before thin shimmerings of cold purple haze. And beyond all else he glimpsed an infinite gulf of darkness, where solid and semi-solid forms were known only by their windy stirrings, and cloudy patterns of force seemed to superimpose or- 
der on chaos and hold forth a key to all the paradoxes and arcana of the worlds we know. (Lovecraft 1963: 104)

The world that Mr. Blake from Wisconsin can see in the Trapezohedron is radically different from the one perceived earlier by Bartram, Fuller, and Thoreau. The wish to penetrate new spaces leads him not just outside the North American continent but outside the planet Earth, into a realm that should have remained unknown to the human subject. The problem is that the protagonist not only sees the distant universe, but also is seen "by some formless alien presence close to him and watching him with horrible intentness" (Lovecraft 1963: 104). The gaze of that "presence" grows more and more unsettling until Blake can no longer bear it and realizes that there is no escape and no hope of resisting it. The worst moments come when the electricity in Providence is down, and that happens more and more often. In sheer darkness, the alien being seems to have easier access to Blake's mind and body, access which must end in their destruction. In a number of his tales, Lovecraft quotes personal documents left by the victims of various sinister powers and this is also the case in "The Haunter of the Dark". When the lights in the city go off again, the demon from the Shining Trapezohedron strikes one last time as a monstrous, "three-lobed burning eye" that takes the protagonist's life. Besides, right before dying (Blake, like Poe's Arthur Gordon Pym of Nantucket, continues writing his diary till the very end), the student mentions the name of Roderick Usher and unites mentally with his monstrous persecutor: "I am it and it is I". (Lovecraft 1963: 115) Ultimately, the boundary between the subject and the alien other has vanished.

The vicissitudes of the American eye and the changes of the scopic regime from Bartram to Lovecraft seem to form a gothic storyline of their own kind. The eye and the subject want to take reality - nature - into their control, and they do it by using various discourses, from that of theology through those of natural science and aesthetics. In the mid-19th century, however, Emerson and Thoreau, each in his own way, fell into 
trouble: the persona of the author of Nature became one with the Divine, while the author of "Ktaadn" understood that the human gaze needs words to account for observation, although no words can match what has been seen beyond the range of human activity. What is more, the predicament worsens whenever some other eye returns the look, particularly as usually it is the eye of an alien: an animal, one's alienated other in a death bird's disguise, or a dreadful "presence" from some alternative dimension. When the eye returns the look, it is nearly always too late for the human subject to retreat. Only Edgar Huntly survived, although it took time before he fully recovered, if he ever did. Both the nameless narrator of Poe's "Tell-Tale Heart" and Lovecraft's Robert Blake perished. They entered two forbidden spaces, off limits: the inner space of insanity and the fantastic outer space of the inhuman.

\section{References}

Brown, Charles Brockden (1984). Edgar Huntly; or, Memoirs of a Sleep-Walker. Sydney J. Krause (ed.). Kent, OH: Kent State University Press.

Bartram, William (1996). Travels and Other Writings. New York: Library of America.

Davis, Robert Con (ed.) (1983). Lacan and Narration: The Psychoanalytic Difference in Narrative Theory. Baltimore and London: The Johns Hopkins University Press.

Edwards, Jonathan (1977). Images or Shadows of Divine Things. Perry Miller (ed.). Westport, Conn.: Greenwood Press.

Foucault, Michel (1973). The Order of Things: Archaeology of the Human Sciences. New York: Vintage Books.

Lovecraft, H[oward] P[hilips] (1963). The Dunwich Horror and Others. S. T. Joshi (ed.). Sauk City, Wis.: Arkham House.

Lowance, Jr., Mason I. (1980). The Language of Canaan: Metaphor and Symbol in New England from the Puritans to the Transcendentalists. Cambridge, MA: Harvard University Press.

Mabbott, Thomas Ollive (ed.) (1978). Collected Works of Edgar Allan Poe, Vol. III. Cambridge, MA: Harvard University Press. 
Porter, Carolyn (1981). Seeing \& Being: The Plight of the Participant Observer in Emerson, James, Adams, and Faulkner. Middletown, Conn.: Wesleyan University Press.

Regis, Pamela (1992). Describing Early America: Bartram, Jefferson, Crevecoeur, and the Influence of Natural History. Philadelphia: University of Pennsylvania Press.

Sears, John F. (1989). Sacred Places: American Tourist Attractions in the Nineteenth Century. Amherst: University of Massachusetts Press.

Spiller, Robert E. (ed.) (1971). The Collected Works of Ralph Waldo Emerson. Vol. I: Nature, Addresses, and Lectures. Cambridge, MA: Harvard University Press.

Steele, Jeffrey (ed.) (1995). The Essential Margaret Fuller. New Brunswick, NJ: Rutgers University Press.

Thoreau, Henry David (1972). The Maine Woods. Joseph J. Moldenhauer (ed.). Princeton, NJ: Princeton University Press.

Worster, Donald (1994). Nature's Economy: A History of Ecological Ideas. Cambridge - New York: Cambridge University Press.

Marek Wilczyński ORCID iD: 0000-0002-6486-6001

American Studies Center University of Warsaw

Al. Niepodległości 22

02-653 Warszawa

Poland

m.wilczynski2@uw.edu.pl 